A R C HIWA , BIBLIOTEKI

I MUZEA KOŚCIELNE 113 (2020)

https://doi.org.10.31743/abmk.10017

KATARZYNA ZIMNOCH* - BIAŁYSTOK

\title{
KSIĘGOZBIÓR KLASZTORU DOMINIKAŃSKIEGO W KRASNYMBORZE W XVIII WIEKU
}

\section{Streszczenie}

Dominikański klasztor w Krasnymborze w województwie trockim został ufundowany w 1684 roku przez Konstancję Chreptowiczową z Dolskich, wdowę po Samuelu Litaworze Chreptowiczu, chorążym starodubowskim, i jej syna Andrzeja. Był to niewielki konwent dominikański należący do prowincji litewskiej pw. Anioła Stróża, który funkcjonował na pograniczu Korony Polskiej i Litwy. Od początku jego powstania zakonnicy starali się zgromadzić odpowiedni księgozbiór. Dzięki zachowanym źródłom, Aktom Konsystorza Generalnego Diecezji Augustowskiej, obecnie przechowywanym w Archiwum Diecezjalnym w Łomży, możemy poznać krasnoborską bibliotekę dominikańską w XVIII wieku. Zawartość księgozbioru wskazuje, że miał on służyć zakonnikom w formacji duchowej i ich pracy duszpasterskiej. Zakon kaznodziejski słynął z ewangeliczno-apostolskiego stylu w walce o dusze ludzkie, stąd znaczną część księgozbioru klasztornego stanowiła literatura teologiczna i homiletyczna, miała ona pomagać w działalności kaznodziejskiej oraz w prowadzeniu misji. Dominikanie krasnoborscy sprawowali również opiekę nad obrazem maryjnym (obraz Matki Bożej Różańcowej), co również wpłynęło na zawartość księgozbioru. W konwencie zgromadzono także literaturę, którą można określić jako polemiczną. Warto zwrócić uwagę, że w omawianym dominikańskim księgozbiorze, mimo że należał do niewielkiego konwentu, znalazło się kilka bardzo cennych zabytków piśmienniczych. Są to ważne ślady po istniejącej niegdyś w tym miejscu placówce zakonnej, która miała być siłą duchową i kulturową oddziałującą na region w którym funkcjonowała.

Słowa kluczowe: księgozbiory historyczne; księgozbiory klasztorne; Krasnybór; dominikanie (prowincja litewska, województwo trockie)

* Katarzyna Zimnoch - dr nauk humanistycznych, adiunkt w Zakładzie Filologicznych Badań Interdyscyplinarnych, Wydział Filologiczny, Uniwersytet w Białymstoku;

e-mail:k.zimnoch@uwb.edu.pl

https://orcid.org/0000-0002-4237-9675 
Istnieje kilka powodów, żeby zająć się krasnoborskim księgozbiorem dominikańskim z przełomu XVIII i XIX wieku. Po pierwsze, nie był on jeszcze w całości obiektem badań, po drugie - jest przykładem biblioteki niewielkiego konwentu istniejącego w województwie trockim w I Rzeczpospolitej. Jego udokumentowanie $\mathrm{i}$ analiza pozwolą na zapoznanie się z zawartością zbiorów niewielkich placówek dominikańskich, a w przyszłości na dokonywanie porównań z innymi klasztornymi bibliotekami. Po trzecie, znane są dwa spisy książek sporządzone w odstępie kilkudziesięciu lat $(1770,1810)$, co daje możliwość prześledzenia zmian występujących w tym księgozbiorze, tym bardziej, że drugi z nich sporządzony został tuż przed kasatą klasztoru. Są to ważne ślady po istniejącej niegdyś tutaj placówce zakonnej, która miała być siłą duchową i kulturową oddziałującą na miejsce, w którym funkcjonowała. Bliższe poznanie biblioteki dominikańskiej w Krasnymborze jest też wkładem do stworzenia w przyszłości syntezy o księgozbiorach dominikańskich w historycznej prowincji litewskiej.

Biblioteki dominikańskie były już wielokrotnie obiektem badań. Zajmowano się zarówno księgozbiorami w poszczególnych konwentach, jak i prowincjach zakonnych ${ }^{1}$. Interesowano się ich historią i funkcjami. Analizowano księgozbiory dominikańskie ${ }^{2}$, kreśląc ogólnie ich tematykę, ale także eksponowano zbiory o treści homiletycznej, historiograficznej, tomistycznej oraz medycznej i ekonomicznej ${ }^{3}$. Badano pozostawione zabytki piśmiennicze, w tym rękopisy muzyczne, a także geografię wydawniczą książek zgromadzonych przez dominikanów ${ }^{4}$.

${ }^{1}$ Przegląd tych badań znajduje się w fundamentalnym opracowaniu bibliograficznym, zob.: R. Żmuda, Bibliografia publikacji o bibliotekach kościelnych za lata 1945-2015, Łódź 2016.

${ }^{2}$ Wśród badaczy bibliotek dominikańskich na podstawie inwentarzy można wymienić m.in. Józefa Kosińskiego, Marka Miławickiego, Maurycego Niedzielę, Annę Markiewicz, Tomasza Stolarczyka, Irenę Szostek i Krystynę Zawadzką.

${ }^{3} \mathrm{~W}$ celu egzemplifikacji tych badań można podać kilka przykładów. Literaturą historiograficzną dominikanów zajmowali się m.in. Sławomir Zonenberg i Iwona Pietrzkiewicz. Zob. S. Zonenberg, Początki dziejopisarstwa dominikańskiego dotyczacego historii własnej wspólnoty: próba systematyzacji, w: Święty Jacek i dziedzictwo dominikańskie, red. E. Mateja, A. Pobóg-Lenartowicz, M. Rowińska-Szczepaniak, Opole 2008, s. 185-193; I. Pietrzkiewicz, Rękopiśmienna spuścizna Faustyna Ciecierskiego jako źródto do dziejów kultury intelektualnej dominikanów prowincji litewskiej poczatku XIX wieku, „Annales Universitatis Paedagogicae Cracoviensis”. Studia ad Bibliothecarum Scientiam Pertinentia, 11 (2013) s. 103-123; I. Pietrzkiewicz, Teksty historiograficzne w środowisku dominikanów Prowincji Litewskiej - wybrany przyktady, „Annales Universitatis Paedagogicae Cracoviensis". Studia ad Bibliothecarum Scientiam Pertinentia, 14 (2016) s. 328-437. Tradycją tomistyczną zajmowały się Monika Mydel i Żaneta Kubic, tematyką ekonomiczną w zbiorach kazań - Anna Zajchowska, a drukami medycznymi - Małgorzata Kamińska-Axer i Małgorzata Czeley-Wybieralska. Zob. M. Mydel, Ż. Kubic, Tradycja tomistyczna w zbiorach Biblioteki Studium oo. Dominikanów w Krakowie. Katalog druków XV-XVIII w. Warszawa 2008; A. Zajchowska, Zagadnienia ekonomiczne w zbiorach kazań modelowych z dominikańskich bibliotek klasztornych w późnym średniowieczu, w: Klasztor w gospodarce średniowiecznej i nowożytnej, red. M. Derwich, Wrocław 2013; M. Kamińska-Axer, M. Czeley-Wybieralska, Starodruki medyczne XVI, XVII i XVIII wieku w Bibliotece Klasztoru OO. Dominikanów w Krakowie, „Archiwum Historii Medycyny”, 40 (1977) s. 468-470.

${ }^{4}$ Zajmowano się także konkretnymi zabytkami piśmienniczymi. Zob. m.in. T. Líchač, Charal nyja rukapísy njasvižskich daminíkancaŭ, w: Nieśwież, red. I. Kotańska, Warszawa 1998, s. 94-98; 
Podkreślano, że biblioteki były świadkami życia danej wspólnoty zakonnej ${ }^{5}$. Niekiedy studia nad księgozbiorami klasztornymi traktowano jako asumpt do przedstawienia fragmentu dziejów kultury intelektualnej i duchowej epoki, a nawet kształtowania tożsamości regionu ${ }^{6}$.

Niestety, w literaturze przedmiotu można znaleźć jedynie nieliczne wzmianki o księgozbiorze dominikańskim w Krasnymborze. Nie wspominali o nim Sadok Barącz ani Jan Marek Giżycki (pseud. Wołyniak), znani historycy zakonu, autorzy fundamentalnych dzieł dotyczących dziejów dominikanów ${ }^{7}$. O jego istnieniu lakonicznie zasygnalizowała Krystyna Zawadzka. Swoje wnioski oparła jedynie na przesłaniu, że tam, gdzie istniał klasztor dominikański, istniała biblioteka „jak wiadomo, nie zakładali oni swych klasztorów bez lektora. Zaś jego obecność w konwencie świadczyła o egzystującej tam bibliotece”. Niestety, autorka syntetycznych prac o bibliotekach dominikańskich nie podała żadnych informacji źródłowych dotyczących księgozbioru krasnoborskiego ${ }^{8}$. Adam Dobroński w opracowaniu Krasnybór $i$ dominikanie zwrócił uwagę tylko na fakt, że znajdowały się tam książki „o wierze prawosławnej, rozmowach (dialogu) z Żydami, przygotowaniach do śmierci" . Nieco więcej informacji pojawiło się w moim artykule Historyczne księgozbiory dominikańskie w powiecie grodzieńskim województwa trockiego w XVII-XIX wiek $u^{10}$. Bardziej interesowano się większymi księgozbiorami dominikańskimi z tego terenu - w Choroszczy i Różanymstoku ${ }^{11}$.

B. Czechowicz, ,Mesco dux et fundator vocatus qui hunc librum tibi christe”. Kilka uwag o późnogotyckim graduale z klasztoru Dominikanów w Raciborzu, w: Święty Jacek Odrowąż i dominikanie na Ślasku, red. A. Barciak, Katowice 2008, s. 315-320; K. Mrowiec, Katalog muzykaliów gidelskich: rękopisy muzyczne kapeli klasztoru gidelskiego przechowywane w Archiwum Prowincji Polskiej OO. Dominikanów w Krakowie, Kraków 1986.

${ }^{5}$ R. Szpor, Biblioteka i archiwum świadkami wspólnoty dominikańskiej, „Życie i Myśl”, 27 (1977) nr 10, s. 45-56.

${ }^{6}$ A.J. Baranowski, Rola zakonów w ksztaltowaniu oblicza miast i regionów w dawnym Wielkim Księstwie Litewskim, „Lituano-Slavica Posnaniensia. Studia Historiae Artium”, 5 (1991) s. 81-94; J. Budniak, Rola Kościołów w kształtowaniu tożsamości Ślaska Cieszyńskiego, w: Chrystus i Jego Kościót, red. nauk. M.J. Uglorz, Bielsko-Biała 2000, s. 185-193; W. Kwiatkowska, Średniowieczne księgozbiory franciszkanów i dominikanów toruńskich i ich znaczenie dla kultury mieszczaństwa, „Zapiski Historyczne”, 67 (2002) z. 1, s. 7-23; K. Ożóg, Uwagi o potrzebach i perspektywach w zakresie badań nad dziejami dominikanów prowincji polskiej w średniowieczu ze szczególnym uwzględnieniem ich kultury intelektualnej i duchowej, w: Dzieje dominikanów w Polsce XIII-XVIII wiek, red. H. Gapski, J. Kłoczowski, J.A. Spież, Lublin 2006, s. 103-121.

${ }^{7}$ S. Barącz, Rys dziejów. Zakony Kaznodziejskie w Polsce, t. 2, Lwów 1861, s. 351; [J.M. Giżycki] Wołyniak, Wiadomości o dominikanach prowincji litewskiej, cz. 1, Kraków 1917, s. 122.

${ }^{8} \mathrm{~K}$. Zawadzka, Ze źródet i stanu badań dotyczacych dawnych klasztornych bibliotek dominikanów w polskich prowincjach, „Nasza Przeszłość”, 39 (1973) s. 226.

${ }^{9}$ A. Dobroński, Krasnybór i dominikanie, Białystok 1993, s. 15.

${ }^{10} \mathrm{~K}$. Zimnoch, Historyczne księgozbiory dominikańskie w powiecie grodzieńskim województwa trockiego w XVII-XIX wieku, w: Arma nostrae militiae. Kultura ksiązki i pisma Zakonu Kaznodziejskiego na ziemiach polskich, red. I. Pietrzkiewicz, M. Miławickiego, Poznań 2019, s. 69-85.

${ }^{11} \mathrm{~K}$. Zimnoch, Biblioteka dominikańska $w$ Choroszczy $w$ XVII wieku, w: Parafia rzymskokatolicka w Choroszczy - 550 lat: księga jubileuszowa, red. T. Kasabuła, A. Szot, Białystok 2009, s. 135148. W. Wróbel, Biblioteka klasztoru dominikanów w Choroszczy w 1828 r. i starodruk St-47 ze 


\section{Klasztor dominikański w Krasnymborze}

Klasztor dominikański w Krasnymborze został ufundowany w 1684 roku przez Konstancję Chreptowiczową z Dolskich, wdowę po Samuelu Litaworze Chreptowiczu, chorążym starodubowskim, i jej syna Andrzeja ${ }^{12}$. Chreptowiczowie herbu Odrowąż pochodzący z województwa nowogródzkiego byli rodem zasłużonym dla tych ziem. Fundowali cerkwie, zbory i kościoły, uposażali klasztory $^{13}$. Wymienia się kilka powodów sprowadzenia dominikanów do Krasnegoboru. Niewątpliwie wśród nich można wskazać potrzebę opieki nad cudownym obrazem Matki Bożej, modlitwę za kolatorów. Podawany jest także motyw osobisty samej inicjatorki fundacji Konstancji, która po śmierci męża wstąpiła do Zakonu św. Dominika. Wcześniej w Krasnymborze próbowano utworzyć klasztor bernardynów, sprowadzając zakonników z pobliskiego Grodna (1661), jednak po 20 latach powrócili oni do macierzystego konwentu ${ }^{14}$. W miejscowości tej funkcjonował także kościół parafialny ${ }^{15}$. Warto zwrócić uwagę na dwie cechy fundacji dominikańskich na Litwie. Po pierwsze, według badań Haliny Gwiazdy wszystkie fundacje dominikańskie $\mathrm{z}$ tego okresu w Wielkim Księstwie Litewskim były zainicjowane przez możnych, co znacznie różniło się w XVII wieku od innych terenów Rzeczpospolitej Obojga Narodów, w Koronie fundacje takie stanowiły wówczas $50 \%$, a na Rusi $-75 \%{ }^{16}$. Po drugie, jak zauważył Sławomir Brzozecki

zbiorów Biblioteki Uniwersyteckiej im. Jerzego Giedroycia w Biatymstoku, w: Małe miasta. Ślady przeszłości, red. M. Zemło, Lublin 2017, s. 257-274; A. Szot, Biblioteka dominikańska w Różanymstoku, „Bibliotekarz Podlaski”, (2004) nr 8, s. 64-78; K. Zimnoch, Historyczna biblioteka dominikańska w Różanymstoku $w$ świetle dziewiętnastowiecznych źródet inwentarzowych-język i proweniencja wydawnicza księgozbioru, „Studia Podlaskie”, 21 (2013) s. 127-147.

${ }^{12}$ Fundacja powstała w drugiej połowie XVII wieku. Większość historyków - o. S. Barącz, J.M. Giżycki, V. Petkus, A. Dobroński, W. Jemielity podaje 1684 rok. Dwóch ostatnich, twierdzi, że była to data ustanowienia fundacji, a sami zakonnicy przybyli rok później, a sama Konstancja wyraziła wolę ulokowania tutaj dominikanów już w 1680 r. Dokładny opis funduszu u Dobrońskiego. Zob. Dobroński, Krasnybór i dominikanie, s. 10-11; W. Jemielity, Sanktuaria maryjne w diecezji łomżyńskiej, Łomża 1991, s. 57. Odpis testamentu Konstancji Dolskiej Chreptowiczowe znajduje się w aktach Konsystorza generalnego diecezji augustowskiej. Zob. Archiwum Diecezjalne w Łomży (dalej: AD Łomża), dz. III, nr 12: Akta Konsystorza Generalnego Diecezji Augustowskiej tyczące się funduszu dominikanów krasnoborskich, k. nlb.

${ }^{13}$ A. Boniecki, Herbarz polski, t. 3, Warszawa 1900, s. 92; G. Ryżewski, Ród Chreptowiczów herbu Odrowąż. Dobra i kariera Chreptowiczów, Kraków 2006; V. Petkus, Dominikonai lietuvos kultūroje, Vilnius 2004, s. 395-397.

${ }^{14}$ Niewyjaśniona jest sprawa bazylianów, którzy według niektórych badaczy mogli być w Krasnymborze. Nie ma na to jednoznacznego potwierdzenia w źródłach. Zob. G. Ryżewski, Sztabin. Dzieje obszaru gminy Sztabin od czasów najdawniejszych do współczesności, Białystok-Sztabin 2002, s. 75-83; Jemielity, Sanktuaria maryjne, s. 57; J. Maroszek, Klasztory Podlasia. Źródła kultury i świadomości narodowej, Białystok 1995, s. 31.

${ }^{15}$ Kościót katolicki na Podlasiu. Zbiór dokumentów erekcyjnych i funduszowych. Krasnybór, wstęp i oprac. G. Ryżewski, Białystok 2000; A. Połujański, Kościół w Krasnymborze, w: Wieniec, Pismo zbiorowe ofiarowane Stanisławowi Jachowiczowi, t. 2, Warszawa 1858, s. 372.

${ }^{16} \mathrm{H}$. Gwiazda, Fundacja i fundatorzy klasztorów dominikańskich w Wielkim Księstwie Litewskim w latach 1648-1696, w: Studia, t. 1, s. 625-635. 
na fundacje dominikańskie na Litwie w tym okresie wybierano małe miasteczka, niekiedy osady wiejskie, inaczej niż w średniowieczu, gdzie budowano klasztory w dużych ośrodkach miejskich. Było to także podyktowane inną strukturą zaludnienia Litwy ${ }^{17}$.

Klasztor krasnoborski wchodził w skład prowincji litewskiej pw. Anioła Stróża powstałej ostatecznie w $1647 \mathrm{roku}^{18}$. Obszar ten znajdował się na terenie rzymskokatolickiej diecezji wileńskiej, w dekanacie grodzieńskim ${ }^{19}$. Po trzecim rozbiorze Polski stolicę biskupią i siedzibę dekanatu włączono do Cesarstwa Rosyjskiego, natomiast Krasnybór znalazł się cztery kilometry od granicy, w Królestwie Polskim. Od 1799 roku parafia była w diecezji wigierskiej, od 1818 roku w diecezji augustowskiej, czyli sejneńskiej, a od 1922 roku pozostaje w diecezji łomżyńskiej. Krasnybór administracyjnie w I Rzeczpospolitej wchodził w skład powiatu grodzieńskiego, województwa trockiego. Obecnie miejscowość ta należy do gminy Sztabin w powiecie augustowskim, w województwie podlaskim.

Klasztory dominikańskie na tym terenie przetrwały do XIX wieku, pozostawiając po sobie trwałe ślady, nie tylko w sferze duchowej, ale także działalności gospodarczej i oświatowej. W 1819 roku rząd Królestwa Polskiego zniósł wiele klasztorów. W wydanym dekrecie znalazło się stwierdzenie, że kasacie podlegają klasztory, które z różnych przyczyn zostały zniszczone, opuszczone lub posiadają małą liczbę zakonników i nie mogą się samodzielnie utrzymać ${ }^{20}$. Odnosiło się to również do Krasnegoboru, gdzie w 1812 roku było tylko trzech zakonników, a dziesięć lat później tylko dwóch. Dwaj ojcowie pozostali jeszcze przy kościele i obaj zmarli w 1825 roku $^{21}$.

\section{Biblioteka krasnoborska}

Księgozbiory powstawały zaraz po utworzeniu klasztoru dominikańskiego ${ }^{22}$. Na początku znajdowały się w nich przede wszystkim księgi liturgiczne, chóralne oraz kaznodziejskie. Pozyskiwano je w różny sposób. Pierwsze książki przybywały razem z zakonnikami sprowadzonymi do ufundowanej placówki, a także jako dary od prowincjałów, fundatorów i innych dobrodziejów zakonu. Księgo-

${ }^{17}$ S. Brzozecki, Litewska prowincja dominikanów, w: Dominikanie, Gdańsk, Polska, Europa. Materiały z konferencji międzynarodowej pt. Gdańskie i Europejskie Dziedzictwo zakonu dominikanów w dziejach Gdańska, red. A. Dekański, Gdańsk-Pelplin 2003, s. 145.

${ }^{18}$ S. Brzozecki, Litewska prowincja dominikanów, ,Rocznik Augustowsko-Suwalski”, 4 (2004) s. $217-236$.

${ }^{19}$ J. Kurczewski, Biskupstwo wileńskie, Wilno 1910, s. 180, 301.

${ }^{20}$ P.P. Gach, Kasaty zakonów na ziemiach dawnej Rzeczypospolitej i Śląska 1773-1914, Lublin 1984, s. 51-63.

${ }^{21}$ W. Jemielity, Zakonnicy w duszpasterstwie, diecezja augustowska czyli sejneńska, „Prawo Kanoniczne: kwartalnik prawno-historyczny”, 41 (1998) nr 1-2, s. 149-171; Maroszek, Klasztory Podlasia, s. 31.

${ }^{22}$ A. Potocki, Biblioteka $w$ dominikańskim studium, „Teofil”, 18 (2002) nr 2, s. 159-169; R. Szpor, Biblioteka i archiwum świadkami życia wspólnoty dominikańskiej, „Życie i Myśl”, 27 (1977) nr 10, s. 45-56; P. Murray, ,Eat the Book”. Study in the Dominican Tradition, „Angelicum”, 81 (2004) nr 2, s. 405-430. 
zbiory powiększano również drogą wymiany, kupna oraz pracy w skryptoriach. Przykładem jest paleotyp z krasnoborską proweniencją przechowywany obecnie w Bibliotece Uniwersytetu Wileńskiego. Zapisy proweniencyjne na starym druku wskazują, że zanim znalazł się w Krasnymborze był w posiadaniu dominikanina Eustachego Konopki, a wcześniej nowicjatu dominikańskiego w Poporciach, $\mathrm{w}$ tej samej prowincji zakonnej23. Obowiązek posiadania książek z określonymi treściami nakładało ustawodawstwo zakonne, ponieważ były one niezbędne zakonnikom w wypełnianiu ich misji. Dlatego też starano się dbać o rozwój księgozbioru klasztornego. Materialnym zabezpieczeniem bytu zakonników krasnoborskich miało być pierwotne uposażenie pochodzące od fundatorów Konstancji Chreptowiczowej oraz jej syna Andrzeja Litawora Chreptowicza ${ }^{24}$. Niestety, było ono niewielkie, poza tym trwał nieustanny konflikt między zakonnikami a przedstawicielami rodu Chreptowiczów ${ }^{25}$. Zakonnicy niejednokrotnie skarżyli się na zbyt szczupłe fundusze, które przeznaczone były na ich funkcjonowanie, co niewątpliwie mogło mieć również swoje przełożenie na stan księgozbioru.

Podstawowymi źródłami do poznania księgozbioru dominikańskiego w Krasnymborze są spisy książek z 1770 roku i 1810 roku obecnie przechowywane w Archiwum Diecezjalnym w Łomży ${ }^{26}$. Informacje o kilku drukach z tego księgozbioru można odnaleźć w katalogach starych druków ${ }^{27}$. Analiza omawianego księgozbioru będzie się opierać na spisie z lat 70. XVIII wieku. Informacje z 1810 roku będą służyły jako uzupełnienie, porównanie i ukazanie rozwoju bądź rozproszenia księgozbioru. Niestety, w obu wykazach podawano informacje o książkach w sposób bardzo lakoniczny, często nieczytelny. Wymieniano nazwisko autora lub jego pseudonim (niekiedy bardziej znany niż nazwisko) lub tytuł książki w sposób skrótowy, całkowicie pominięto adresy wydawnicze - miejsce i rok wydania. Poszczególne pozycje nie zostały ponumerowane, wymieniano książki, jedną po drugiej. Mimo że dokładność wykonania spisów książek, zamieszczonych w inwentarzach klasztornych i protokołach wizytacyjnych, budzi wiele zastrzeżeń, to jednak - jak podkreślano już wielokrotnie w literaturze przedmiotu - są one najlepszymi, dostępnymi obecnie źródłami ujawniającymi ich zawartość28.

${ }^{23}$ Vilniaus universiteto bibliotekos paleotipai. Katalogas, oprac. N. Feigelmanas, I. Daugirdaitè, P. Račius, Vilnius 2003, s. 130 (poz. 471. Dionysios Areopagita, S. Dionysii Areopaitae, martyris inclyti, Athenarum episcopi et Galliarum apostoli Opera, translatio nova Ambrosii Florentini, Venetiis 1546). Jednak książka ta nie została spisana w XVIII wieku w dominikańskim klasztorze krasnoborskim. Prawdopodobnie wcześniej znalazła nowego właściciela, na co zresztą wskazują kolejne zapisy proweniencyjne: Michał Piąrrowski; Stanisław Sorcz.

${ }^{24}$ Kościót katolicki na Podlasiu, s. 18.

${ }^{25}$ Konflikt i jego prawdopodobne przyczyny zostały opisane w publikacjach Adama Dobrońskiego i Grzegorza Ryżewskiego. Zob. Dobroński, s. 11-14; Ryżewski, Sztabin, s. 81-82.

${ }^{26}$ AD Łomża, dz. III, nr 12: Akta Konsystorza generalnego diecezji augustowskiej tyczące się funduszu dominikanów krasnoborskich.

${ }^{27}$ Vilniaus universiteto bibliotekos paleotipai, s. 130.

${ }^{28}$ Zob. m.in.: M. Miławicki, Inwentarze i spisy bibliotek klasztorów dominikańskich skasowanych w guberniach zachodnich Cesarstwa Rosyjskiego $w$ XIX w. Stan źródet i miejsca ich przechowywania, „Hereditas Monasteriorum”, 1 (2012) s. 141-172. 


\section{Wielkość księgozbioru}

Księgozbiór dominikanów krasnoborskich nie był duży. W latach 70. XVIII wieku, według spisu zamieszczonego w inwentarzu, liczył 57 pozycji, a w 1810 roku wykazano już tylko 30 . W spisach tych pojawiały się zarówno książki drukowane, jak i rękopiśmienne. Należy zwrócić uwagę, że są to jedynie dane szacunkowe. W spisach sporadycznie pojawia się informacja o liczbie tomów i egzemplarzy danego tytułu. Niektórzy badacze przy takich problemach mnożą tytuł przez 3-4, żeby uzyskać według nich rzeczywistą liczbą woluminów ${ }^{29}$.

Porównanie omawianych spisów pokazuje znaczną różnicę $\mathrm{w}$ stanie księgozbioru na przestrzeni kilkudziesięciu lat. W spisie z 1810 roku odnotowano jedynie 16 książek z 1770 roku. Były to przede wszystkim egzemplarze Pisma Świętego, kilka pozycji z zakresu literatury teologicznej (m.in. Klaudiusz Lacroix, Theologia moralna) i homiletycznej (Onufry Danilewicz, pseud. Taczalski, Nowy Aaron Nazareński) oraz szkolnej (np. J. Sperlings, Execitationes Phisica czy też dzieła Cycerona i Owidiusza). Należy zwrócić uwagę, że kilka książek mogło być zapisane pod jedną pozycją (np. dzieła Onufrego Danilewicza). W ciągu 40 lat z księgozbioru ubyło ponad 40 książek. W 1810 roku nie wymieniono znajdujących się wcześniej dzieł św. Tomasza z Akwinu wielu zbiorów kazań (np. Fabiana Birkowskiego, Benedykta Zawadzkiego, Jana Andrzeja Gintowta Andrzejkiewicza), a także nie odnotowano żadnej pozycji z zakresu prawa kościelnego, dekretów i konstytucji zakonnych (w 1770 roku było ich 4). Nie wymieniono również książek związanych z kultem maryjnym (m.in. J. F. Sapieha, Monumenta antiquiatum Marianorum; R. Śmiarowski, Fontanna Mistyczna z Obrazu Náyśw: Panny Maryey) czy też kilku dzieł polemicznych (np. T. Arenta, Studium polemicum). Mogły być one „zaczytane”, wypożyczone i niezwrócone, co według Marii Pidłypczyk-Majerowicz było jedną z najczęstszych przyczyn ubytków księgozbiorów do końca XVIII wieku. Zakonnicy mogli także celowo nie wpisywać wszystkich pozycji do spisu tuż przed kasatą klasztoru ${ }^{30}$.

Należy także zwrócić uwagę, że w 1810 roku pojawiły się nowe tytuły. Na początku spisu odnotowano księgi liturgiczne z zakrystii, kilka książek z informacją typu: „Księga in folio zepsuta introligacyi Autora niewiadomego bez oprawy”. Jednak wśród nowych pozycji znalazły się m.in. kazania Józefa Madejskiego (Rok kaznodzieyski), Augustyna Rakiewicza (Latorośl piętnastu róż), Maksymiliana Karpowicza (Kazania na niedziele, t. 2) i Filipa Hartunga oraz książka autorstwa ks. Krzysztofa Kluka. Kilka z tych pozycji ukazało się już po 1770 roku (M. Karpowicza, K. Kluka). Wskazuje to na ciągłe powiększanie się księgozbioru nawet w trudnych okresach działalności klasztoru. Jednak odnotowano też pozycje, które były wydawane dużo wcześniej, dlatego można wysnuć wnioski, że książki te

${ }^{29}$ T. Stolarczyk, Biblioteka kapituly kolegiackiej $w$ Wieluniu w świetle inwentarza z 1766 roku, „Rocznik Wieluński”, 11 (2011) s. 48; P. Kardyś, Biblioteka przykolegiacka w Wiślicy (XV-XVIII w.), „Archiwa, Biblioteki i Muzea Kościelne”, 82 (2004) s. 87.

${ }^{30}$ M. Pidłypczak-Majerowicz, Biblioteki i bibliotekarstwo zakonne na wschodnich ziemiach Rzeczypospolitej w XVII-XVIII wieku, Wrocław 1996, s. 48, 102. 
znajdowały się w zbiorze wcześniej, ale nie były spisane (np. były wypożyczone), może też trafiły do zbiorów dominikanów krasnoborskich po 1770 roku w formie daru czy też w wyniku zapisu testamentowego lub przybyły z zakonnikami.

$\mathrm{W}$ innych klasztorach dominikańskich w tej samej prowincji było zdecydowanie więcej książek. Największe zbiory zgromadzono w Grodnie, Połocku i Wilnie. Liczyły one po kilka i kilkanaście tysięcy woluminów (w Grodnie i Połocku ok. 11 tys. woluminów, w konwencie Ducha Świętego w Wilnie - ok. 6 tys. woluminów) ${ }^{31}$. Natomiast $\mathrm{w}$ pierwszej połowie XIX wieku w Choroszczy odnotowano 516 tytułów (tysiąc woluminów) ${ }^{32}$, w Różanymstoku ponad 610, w Klimówce 330, w Kalwarii Żmudzkiej - 348 33 , a Poporciach $-918^{34}$.

\section{Zawartość księgozbioru}

Książki z konwentu krasnoborskiego spisano bez wyróżnienia działów. Prawdopodobnie wynikało to $\mathrm{z}$ niewielkiego liczbowo księgozbioru. $\mathrm{W}$ innych bibliotekach dominikańskich z tej prowincji książki spisywano w różny sposób, najczęściej według alfabetu, formatów, działów wiedzy, kryteriów językowych, a także ułożenia książek na półkach ${ }^{35}$. Wiesław Wróbel, charakteryzując XIX-wieczną bibliotekę w Choroszczy, podkreślał, że działy oznaczone literami od A do D obejmowały książki o tematyce religijnej, a działy: F, I, J, L, M, N i R zawierały zbiory z zakresu nauk ,świeckich” (historii, matematyki, przyrody, filozofii, gramatyki, retoryki, poetyki, dzieła starożytne, filozofii i konstytucji ${ }^{36}$.

Zaczynając charakterystykę biblioteki od Pisma Świętego i ksiąg liturgicznych, należy zwrócić uwagę, że dominikanie krasnoborscy w swojej bibliotece posiadali kilka wydań Pisma Świętego, m.in.: łaciński przekład św. Hieronima, tzw. Wulgata (w spisie: „Biblia vulgate additions sacre”), osobno spisane różne wydania Starego i Nowego Testamentu, a także Ewangelia w języku łotewskim (w spisie: „Evangelia Lothavica”) oraz księgi liturgiczne. W spisie z 1810 roku odnotowano również Mszały, Ewangeliczkę, Agendkę oraz Martyrologium. Należy zwrócić uwagę, że w 1770 roku egzemplarze Pisma Świętego nie zostały wymienione na pierwszym miejscu. Pierwszy zapis informujący o nich - „Biblia sacrosancta" - pojawił się dopiero na 8 pozycji, po kazaniach i innych książkach. Pozostałe egzemplarze odnotowano niemalże pod koniec spisu. Podobnie było w 1810 roku, gdzie wykazano już jedynie dwa egzemplarze Pisma Świętego.

Uwagę zwraca informacja o „Ewangelii Lothavica”. Może być to Ewangelia pro Dominicis lingua Lothavica z $1672^{37}$ lub Ewangelia toto anno singulis dominicis et festis diebus juxta antiquam ecclesiae consuetudinem in Livonia lo-

${ }^{31}$ Miławicki, Inwentarze i spisy bibliotek, s. 141-172.

${ }^{32}$ Wróbel, Biblioteka klasztoru dominikanów, s. 261.

${ }^{33}$ A. Pacevičius, Žemaičiu Kalvarijos dominikonu bibliotekos autoriai ir knygos 1820 metais, „Knygotyra”, 36 (2000) s. 290-309; tenże, Vienuolunu bibliotekos Lietuvoje 1795-1864 metais, Vilnius 2005, s. 165.

${ }^{34}$ A. Pacevičius, Vienuolunu bibliotekos Lietuvoje 1795-1864 metais, Vilnius 2005, s. 163-164.

${ }^{35}$ Zimnoch, Historyczne księgozbiory dominikańskie, s. 69-85.

${ }^{36}$ Wróbel, Biblioteka klasztoru dominikanów, s. 262.

${ }^{37}$ Ewangelia pro Dominicis lingua Lothavica, Vilnae 1672, E XVI, s. 113. 
thavis praelegi solita w przekładzie Jerzego Elgera, wydawana w latach: 1672, 1753, $1758^{38}$ lub też w tłumaczeniu Jana Łukaszewicza z 1753 roku $^{39}$. Niestety, ze względu na lakoniczny zapis nie da się tego jednoznacznie rozstrzygnąć. Wszystkie te tłumaczenia, wytłoczone w drukarni akademickiej (jezuitów) w Wilnie, zapisały się znacząco w historii piśmiennictwa łotewskiego. Były zasługą jezuitów, którym potrzeba dokonywania przekładów podstawowych prawd wiary bezpośrednio wiązała się z misjami, katechizacją i kaznodziejstwem, tym bardziej na terenach, które przez wiele lat miały podlegać rekatolizacji ${ }^{40}$. Jerzy Elger (15861672), doświadczony misjonarz, z pochodzenia Łotysz, był wychowankiem jezuitów braniewskich (1605-1607), a następnie wileńskich. Zasłynął jako dobry kaznodzieja, a przede wszystkim gorący propagator języka ojczystego (łotewskiego), zarówno w mowie, jak i piśmie. Przełożył i opublikował wiele tekstów religijnych, m.in. Cantiones spirituales ex latinis, germanicis et polonicis translatae in idioma lothavicum additis pluribus (Vilnae 1673), Catechismus seu brevis institutio doctrinae christianae [...] in gratiam gentis lothavicae (Vilnae 1672), słownik: Dictionarium polono-latino-lottavicum. Opus posthumum in gratiam studiosae iuventutis in lucem datum (Vilnae 1683) oraz omawiane tłumaczenie ewangelii niedzielnych: Evangelia toto anno singulis dominicis et festis diebus juxta antiquam ecclesiae consuetudinem in Livonia lothavis praelegi solita (Vilnae $1672,1753,1758)^{41}$. Równie oddanym swojej działalności translatorskiej był misjonarz Jan Łukaszewicz (1699-1779), który wydał w dialekcie łatgalskim kilka

${ }^{38}$ Ewangelia toto anno singulis dominicis et festis diebus juxta antiquam ecclesiae consuetudinem in Livonia lothavis praelegi solita. Ex latino in lothavicum idioma translata, Vilnae, typ. Acad. S.I. 1672. E, XVI, s. 45-6. Wszystkie te dzieła zachowane do dziś opisuje: K. Cepiene, I. Petrauskiene, Vilniaus akademijos spaustuves leidiniai 1576-1805, Vilnius 1979, s. 240-241.

${ }^{39}$ Evangelia Toto Anno singulis Dominicis et Festis diebus juxta antiquam Ecclesiae consuetudinem in Livonia Lothavis praeiegi solita, cum precibus et precatiunculis nonnullis, cura quorundam ex Clere Livonica recentissime juxta usitatierem loquendi modum Lothavicum versa et translata ac in lucem edita, Anno quo aeternum Patris Verbum per Angelos in terris evangelizatum est, Vilnae: S.J. 1753. Zob. Evangelia toto anno 1753: pirmā latgaliešu grämata, oprac. A. Stafecka, Ryga 2004.

${ }^{40}$ Potrzeba tłumaczenia książek służących ewangelizacji na język łotewski pojawiła się w XVI wieku. Po inkorporacji Inflant, wraz z Rygą i arcybiskupstwem ryskim jezuici zabiegali o rekatolizację tych ziem. Ich przedstawiciele jednoznacznie apelowali, że służyć ma temu znajomość miejscowych języków, a co się z tym wiąże, również przekładów potrzebnych książek. Temat ten ma już dosyć bogatą literaturę. Zob. m.in.: L. Grzebień, Znaczenie jezuitów w Rzeczypospolitej na przetomie XVI i XVII w., „Studia Bobolanum”, 3 (2010) s. 49-50; L. Grzebień, J. Zaryczny, Języki narodowe w działalności jezuitów w Inflantach, „Analecta Cracoviensia”, (1995) nr 27, s. 404-405. Zajmowano się już także samymi zabytkami piśmienniczymi, ich genezą powstania oraz autorami thumaczeń. Zob. m.in.:. Evangelia toto anno 1753 : pirmā latgaliešu grämata, oprac. A. Stafecka, Ryga 2004; Georgius Elger 1585-1672. Geistliche Catholische Gesänge... (Braunsberg 1621), oprac. M. Grudule, J. Prusinowska, M. Solarz, Warszawa 2018.

${ }^{41} \mathrm{H}$. Keferstein, Pisarze zwiazani z Braniewem na przełomie XVI-XVII wieku, „Komunikaty Mazursko-Warmińskie", (1980) nr 4, s. 516; J. Poplatek, K. Świerkowski, Elger Jerzy (1586-1672), w: Polski stownik biograficzny, t. 6, Kraków 1948, s. 227. Dzieła zachowane do dziś opisuje: K. Cepiene, I. Petrauskiene, Vilniaus akademijos spaustuves leidiniai 1576-1805, Vilnius 1979, s. 240-241. 
pism religijnych. Najbardziej znana jest wspominana Evangelia toto anno... (Vilnae 1753), zawierająca thumaczenie ewangelii niedzielnych i świątecznych. Jest to pierwszy, i co ważne zachowany do dzisiaj, zabytek piśmiennictwa łatgalskiego ${ }^{42}$. Obaj wspomniani jezuici zasłynęli jako wybitni znawcy języka łotewskiego.

Można się zastanawiać, dlaczego omawiane łotewskie thumaczenie ewangelii pojawiło się w dominikańskiej bibliotece w Krasnymborze. Najbardziej prawdopodobne wydaje się, że księga przybyła tutaj razem z którymś z zakonników. Dominikanie, często przeprowadzali misje na pogranicznych, wielowyznaniowych terenach lub też regionach o skomplikowanych strukturach politycznych, społecznych i religijnych. Niestety brak informacji o dacie wydania nie pozwala określić kręgu osób, którym mogła ona służyćc ${ }^{43}$. Wiadomo też, że takie thumaczenie znajdowało się w innej bibliotece dominikańskiej prowincji litewskiej - w Agłonie ${ }^{44}$.

Dominikanie krasnoborscy posiadali dzieła z zakresu teologii, zarówno, dogmatycznej, moralnej, pasterskiej, jak i ascetycznej. Dysponowali również różnego rodzaju pomocami teologicznymi. Oczywiście, posiadali dzieła św. Tomasza z Akwinu, teologa scholastycznego, filozofia, jednego z najbardziej znanych członków tego zakonu w XIII wieku. Były to pozycje bardzo często występujące w bibliotekach dominikańskich, świadczące o scholastycznym profilu studiów zakonu, o co się upominały kapituły generalne m.in. w Rzymie (1650) i Bolonii $(1705)^{45}$. W ich zbiorach znalazły się także dzieła m.in. kartuza Antoniego Moliny Instructio Sacerdotum, Klaudiusza Lacroix Theologia moralis, a także Franciszka Costera. W 1810 roku dodatkowo wymieniono dzieła Filipa Hartunga. Kilku książek nie da się dzisiaj zidentyfikować ze względu na lakoniczne zapisy: „Teologia moralna bez początku niewiadomego Autora”, „Teologia Moralis”, „Casuistica”, jednak wskazują one na tematykę zbiorów. Wśród pomocy teologicznych można wymienić dzieło pisarza ascetycznego, jezuity Kaspra Drużbickiego Nauka o przygotowaniu się do światobliwej śmierci, które miało pomóc wykreować i umocnić pojęcie ,dobra śmierć“. Tego typu pomoce były dosyć popularne w okresie nowożytnym. Obok traktatu Drużbickiego, z tego okresu najczęściej wymienia się również dzieła Jana Janusowskiego (1550-1613) Nauka umierania chrześcijańskiego, także jako konającego pana Boga oddawać i czego na ten czas pilnować trzeba... oraz Jana Morawskiego (1633-1700) Droga przed Bogiem śmierć świętych albo dyspozycja nad śmiercią ${ }^{46}$. Kolejną pozycją, na którą warto zwrócić uwagę, to rozmyślania i czytania duchowe na rok liturgiczny Jana Drewsa Breviarim asceti-

\footnotetext{
${ }^{42}$ Evangelia toto anno 1753 : pirmā latgaliešu grāmata, oprac. A. Stafecka, Ryga 2004; S.F. Kolbuszewski, Łukaszewicz Jan, w: Polski stownik biograficzny, t. 18, Wrocław 1973, s. 540-541.

${ }^{43}$ Ks. Witold Jemielity ustalił krótką listę zakonników, którzy przebywali w klasztorze krasnoborskim. Zob. Jemielity, Sanktuaria maryjne, s. 59.

${ }^{44}$ W. Jemielity, Basilica Aglonensis - Aglonas bazilikas vēsture, http://www.vietas.lv/index. php?id=233\&p=10id=799 (dostęp: 20.06.2019).

${ }^{45} \mathrm{P}$. Krupa, Wyksztatcenie filozoficzne dominikanów polskich $w$ XVIII stuleciu: Theses ex uniwersa philosophia Ludwika de Mathy OP (1753), w: Dominikanie. Gdańsk-Polska-Europa. Materiaty z konferencji międzynarodowej pt. Gdańskie i Europejskie dziedzictwo Zakon Dominikanów w dziejach Gdańska, Gdańsk-Pelplin 2003, s. 93.

${ }^{46}$ B. Rok, Człowiek wobec śmierci w kulturze staropolskiej, Wrocław 1995.
} 
cum, medytacje pasyjne, prawdopodobnie autorstwa św. Alfonsa Marii Liguori czy też rozważania na Wieki Tydzień („Officium hebdomadae sanctae”).

Należy podkreślić, że jednym z podstawowych zadań dominikanów było kaznodziejstwo. Słynęli oni ze swoich misji ludowych oraz pomocy duszpasterskiej w parafiach ${ }^{47}$, byli też autorami licznych dzieł homiletycznych, które trafiały do bibliotek zarówno klasztornych, jak i kościelnych ${ }^{48}$. Klasztor dominikanów krasnoborskich znajdował się w bezpośrednim sąsiedztwie kościoła parafialnego. Mieli oni pomagać proboszczowi i obsługiwać kościół filialny w Sztabinie ${ }^{49}$. W Krasnymborze znajdowały się zbiory kazań, m.in. autorstwa dominikanów: Fabiana Adama Birkowskiego, Piotra Drogoszewskiego, pijara Benedykta Zawadzkiego, trynitarza Onufrego od Najświętszego Sakramentu ${ }^{50}$ Nowy Aaron Nazareński oraz Roszczka Aaronowa, a także jezuity Jana Andrzeja Gintowt-Andrzejkiewicza Ziarno gorczyczne męki Zbawiciela. Dodatkowo inwentarz z 1810 roku wymienia również kazania pijara Józefa Madejskiego (imię zakonne Idzi od św. Józefa) Rok Kaznodzieyski Albo Kazania Na Niedziele całego Roku, reformata Franciszka Rychłowskiego, jezuity Filipa Hartunga i karmelity Maksymiliana od Najświętszej Maryi Panny (Maksymilian Karpowicz) Kazania Na Niedziele Całego Roku i Święta Ruchome dogmatyczno-moralne. Był to ważny dział w księgozbiorze, niezwykle pomocny w duszpasterstwie, bo jak słusznie zauważyła Magdalena Ślusarska literatura kaznodziejska towarzyszyła przez stulecia wszelkim okolicznościom życia człowieka, zarówno prywatnego - narodzinom, chrztom, ślubom, rocznicom, powołaniom, śmierci, jak i publicznego - sejmom, elekcji nowego monarchy, trybunałom, wszelkim wystąpieniom zbrojnym ${ }^{51}$.

Przy głoszeniu kazań niezwykle ważne były umiejętności budowania perswazyjnej wypowiedzi. W kształceniu dominikanów uważano, że retoryka jest niezbędnym elementem wykształcenia, w zbiorach klasztornych, w tym krasnoborskim, również zachowały się dzieła m.in. Cycerona, Owidiusza, Plutarcha, książka profesora retoryki ks. Bartłomieja Ludery (Cithara Apollinis), panegiryki (np. Marcina Oślinskiego Pangyricus seremissimo ac potentissimo Augusto II Reg. Poloniarum) czy też inne pomoce dydaktyczne (w omawianym spisie pojawiły się lakoniczne informacje o takich książkach jak: „Rethorica”). Służyły one również w nauce młodzieży. Józef Pelczar opisywał ten proces nauczania:

${ }^{47}$ O duszpasterstwie parafialnym zakonów zob. J. Flaga, Działalność duszpasterska zakonów $w$ drugiej połowie XVIII wieku, Lublin 1986, s. 41-138.

${ }^{48}$ T. Moskal, Dzieła homiletyczne kaznodziejów dominikańskich $w$ XVIII-wiecznych bibliotekach archidiakonatu sandomierskiego, „Saeculum Christianum”, 16 (2009) nr 1, s. 129-136; J. Szady, Zasięg kaznodziejskiej literatury dominikańskiej w bibliotekach parafialnych $w$ końcu XVIII wieku w diecezji krakowskiej, w: Święty Jacek i dziedzictwo dominikańskie, red. E. Matei, A. Pobóg-Lenartowicz, M. Rowińska-Szczepaniak, Opole 2008, s. 259-272; T. Gałwiaczek, Ksztaltowanie mentalności chrześcijanina w świetle kazań dominikańskich czasów saskich, Torun 2009.

${ }^{49}$ Jemielity, Zakonnicy w duszpasterstwie, s. 163; tenże, Sanktuaria, s. 59.

${ }^{50}$ Właściwie: Aleksander Kazimierz Danilewicz (imię zakonne Onufry od Najświętszego Sakramentu; pseud. Taczalski; Onufry Danilewicza).

${ }^{51}$ M. Ślusarska, Kaznodziejstwo epoki stanisławowskiej - inspiratorzy, twórcy, odbiorcy, „Napis” Seria II (1995) s. 106. 
Metoda była taka, że obok wykładu prawideł retoryki, odczytywano celniejsze mowy lub ustępy z innych dzieł Cycerona, a także Kwintyliana, Arystotelesa, Demostenesa i Izokratesa i uczono młodzież, jak odnośnie do różnych przedmiotów i celów wymowy naśladować tych mistrzów. Główną uwagę zwracano przytem na gładkość i harmonię stylu, trafny dobór figur retorycznych i staranną budową okresów, - słowem, na zewnętrzną stronę wymowy... ${ }^{52}$.

Inną pomocą, która miała uczyć zasad wymowy kościelnej, kładąc nacisk na naturalny styl i treść mógł być, występujący w spisie książek, wielokrotnie wydawany podręcznik homiletyki Kazimierza Wijuka Kojałowicza Modi LX sacrae orationis varie formandae (Sześćdziesiat sposobów komponowania kazań) ${ }^{53}$.

Pomocą mogły służyć także słowniki i leksykony. W księgozbiorze znajdował się słownik, który opisano jako „liber latinus trium linguarum”. Występowanie w zbiorze ewangelii w języku łotewskim może dać pewien asumpt do postawienia hipotezy, że mógł to być Dictionarium polono-latino-lothavicum ... opus posthumum (1683) Jerzego Elgera. Słownik ten jest wzorowany na znanym leksykonie Knapskiego, lecz Elger, zamiast języka greckiego wstawił łotewski ${ }^{54}$. Wydaje się jednak, że ewangelia w języku łotewskim znalazła się tutaj za pośrednictwem jednego z zakonników. Nie prowadzono tu bowiem szczególnych działań czy studiów związanych $\mathrm{z}$ ewangelizacją w tym języku. Mógł to być słownik łacińsko-polsko-litewski Konstantego Szyrwida (Dictionarium Trium Lingvarum) ${ }^{55}$, wspominany thesaurus (słownik językowo-encyklopedyczny) Grzegorza Knapskiego (Thesaurus polono-latino-graecus seu promptuarium lingua Latinae et Graece $^{56}$ lub słownik łacińsko-niemiecko-polski Franciszka Mymera Dictionarius trium linguarum: Latine, Teutonice et Polonice ${ }^{57}$. Wydaje się, że jest to ten ostatni, ponieważ w spisie z 1810 roku w poz. 24 pojawia się zapis „Dykcyonarz łaciński niemiecki”. Najprawdopodobniej w ten sposób zapisano trójjęzyczny słownik Mymera ${ }^{58}$.

${ }^{52}$ J. Pelczar, Zarys dziejów kaznodziejstwa w kościele katolickim, cz. 2: Kaznodzieje Polsce, t. 2, Kraków 1896, s. 80.

${ }^{53}$ L. Piechnik, Kojałowicz Wijuk Kazimierz, w: Stownik polskich teologów katolickich, t. 2, Warszawa 1982, s. 317; Kazimierz Wijuk Kojałowicz, Modi LX sacrae orationis varie formandae. A P. Casimiro Wiiuk Koialowicz ... in gratiam incipientium collecti et praxibus illustrati ..., Antverpia $1668,8^{0}$.

${ }^{54}$ K. Świerkowski, Wilno kolebka drukarstwa łotewskiego, Wilno 1932, s. 24.

${ }^{55} \mathrm{~K}$. Szyrwid, Dictionarium trium linguarum in usum studiosae juventutis, Wilno 1629; wyd. następne: Wilno 1631; Wilno 1642; Wilno 1677; Wilno 1713; Wilno 1718.

${ }^{56}$ G. Knapiusz (Knapski; Gregorius Cnapius), Thesaurus polono-latino-graecus seu promptuarium lingua Latinae et Graece [...], F. Caesario, Cracoviae [Kraków] 1621.

${ }^{57}$ F. Mymer (Mymerus), Dictionarius trium linguarum: Latine, Teutonice et Polonice potiora vocabula continens nunc denuo pluribus in locis auctus in titulis per seriem alphabeti concinnatus tum peregrinantibus tum domi desidentibus et quibuslibet tribus loqui linguis cupientibus maxime necessarius et utilissimus, Vietor, Cracoviae [Kraków] 1528.

${ }^{58}$ H. Łopaciński., Najdawniejsze stowniki polskie drukowane, „Prace Filologiczne”, 5 (1899) s. 393454, 586-605. Zob. też: Słowniki dawne i współczesne. Internetowy przewodnik edukacyjny, red. M. Bańko, M. Majdak, M. Czeszewski, http://www.leksykografia.uw.edu.pl/ (dostęp: 20.06.2019). 


\section{Kult maryjny}

W omawianym księgozbiorze widać widoczne zainteresowanie kultem maryjnym. Jest to zrozumiałe, gdyż jedną z najważniejszych przyczyn sprowadzenia dominikanów do Krasnegoboru była potrzeba opieki nad obrazem maryjnym. W 1688 roku Andrzej Chreptowicz potwierdzając fundusz swojej matki Konstancji dany dominikanom w Krasnymborze, motywował to w sposób następujący: „Aby przy cudownym obrazie Najświętszej Panny od bardzo dawna słynącego cudami, na zawsze sława Boża nie ustawała" 59 . Według historyków obraz ten pochodzi z XVII wieku, został wykonany techniką olejną na płótnie (wymiary 110 na $93 \mathrm{~cm}$ ). Przedstawia Maryję z Dzieciątkiem Jezus na lewym ramieniu, w prawej dłoni dzierżącą berło. Dziecię w lewej ręce trzyma jabłko królewskie, w prawej różaniec. Postać Maryi okrywa suknia z mosiężnej blachy, srebrzona i złocona, zdobiona nimbami, berłem, różańcem i półksiężycem. Wokół ich głów widnieją złocone nimby, na które nałożone są złote korony. Zasłonę obrazu stanowi wizerunek świętego Antoniego, który na jednej ręce trzyma Dzieciątko, a w drugiej lilię. Korona i sukienka pochodzą już z późniejszego okresu. Niestety, nie znany jest jego autor, obraz nie posiada też kopii. Adam Dobroński konstatuje, że do wzmożenia kultu obrazu krasnoborskiego mogły przyczynić się, tak jak w innych miejscach, wojny z II połowy XVII wieku. Wierni przybywali z okazji świąt maryjnych, a także na odpusty, które się odbywały na Trzech Króli i Przemienienie Pańskie. Źródła opisują, że pielgrzymi przybywali „,z dalekich stron”, „lud z różnych gromadził się parafii”. Dziewiętnastowieczne granice przerwały napływ wiernych. Badacze podkreślają, że przy obrazie zostawiano dużo wotów („obraz Matki Najś[więtszej] Łaskami słynący, przy którym też wotów różnych wielkie mnóstwo było" ${ }^{\circ 0}$ ), które zdobiły ołtarze. Pod koniec XVIII wieku zostały one wycenione, utensylia kościelne w części przekazano na potrzeby insurekcji kościuszkowskiej ${ }^{61}$. Natomiast nie powstały specjalne modlitwy czy też pieśni związane z tym miejscem. Źródła nie informują również o źródełku.

Należy zwrócić uwagę, że kult maryjny był bardzo rozpowszechniony w klasztorach dominikańskich. W prowincji litewskiej obrazy z wyobrażeniem Maryi czczono m.in. w Sejnach, Różanymstoku, Klimówce i Krasnymborze ${ }^{62}$.

${ }^{59}$ AD Łomża, III, 12, bez pag.; Jemielity, Sanktuaria maryjne, s. 65.

${ }^{60}$ S. Barącz, Cudowne Obrazy Matki Najświętszej w Polsce, [Lwów] 1891, s. 132.

${ }^{61}$ W. Guzewicz, R. Skawiński, Sanktuaria w diecezji ełckiej (1992-2012), „Civitas et lex”, (2017) nr 3 (15), s. 67-76; Dobroński, Krasnybór i dominikanie, s. 9, Jemielity, Sanktuaria maryjne, s. $55-78$.

${ }_{62}$ J. Tomalska, Stynące taskami obrazy Matki Boskiej z Dzieciatkiem w kościołach dominikańskich zachodniej części dawnego województwa trockiego, w: Dominikanie na ziemiach polskich w epoce nowożytnej, red. A. Markiewicz, M. Miławicki, Kraków 2009, s. 369-392. Szerzej o sanktuariach maryjnych na ziemiach polskich w okresie przedrozbiorowym zob. A. Witkowska, The Cult of the Virgin Mary in Polish religiousness from the 15-th to the 17-th Century, w: The common Christian roots of the European nations. An international colloqium in the Vatican, t. 2, Florence 1982, s. 467-478; J. Marecki, Sanktuaria zakonne na ziemiach polskich na przełomie XVII i XVIII $w$., w: Kultura intelektualna $w$ zakonach polskich $w$ XVII i XVIII wieku. Materiały z sesji naukowej Katedry Historii Zakonów zorganizowanej 27 października 2005 r., red. M. Łobozek, Kraków 2006, s. $25-56$. 
Sanktuaria te były znanymi ośrodkami kultu maryjnego w historycznej diecezji wileńskiej ${ }^{63}$.

Dominikanie krasnoborscy posiadali zarówno kazania maryjne, jak i książki dotyczące obrazów Matki Bożej. Wśród autorów kazań maryjnych można wymienić przede wszystkim Augustyna Rakiewicza (Latorośl Piętnastu Roz $\mathrm{Na}$ Pamiątkę Piętnasty Tajemnic Różańcowych, Piętnastą Kazaniami O Różańcu S. Światu Pokazana) oraz Maksymiliana Karpowicza i Onufrego Taczalskiego. Natomiast o obrazach można było przeczytać w książkach autorstwa Remigiana Śmiarowskiego (Fontanna Mistyczna z Obrazu Nayśw. Panny Maryey, Od Roku 1684. Cudownymi Laskami w Kościele Wileńskim Łukiskim SS. Apostołów Filippa y Jakuba Zakonu Kaznodzieyskiego Prowincyi Litewskiey shynacego, Wilno 1737) oraz Jana Fryderyka Łukasza Sapiehy (Monumenta Antiquitatum Marianarum, o obrazie kodeńskim). Opieka nad cudownym obrazem i troska o kult maryjny były jednym z ważniejszych zadań dominikanów, którzy w ten sposób przyczyniali się do szerzenia tradycyjnej pobożności ludowej ${ }^{64}$.

\section{Polemiki i inne}

W omawianym księgozbiorze znajdowały się książki o charakterze polemicznym. W tym miejscu można wymienić prace m.in. jezuity Jana Alojzego Kuleszy Wiara prawosławna i dominikanina Piotra Drogoszewskiego Tarcza wiary Chrystusowej, która uzbrojony Polak łatwo może przytępić oręż lutrów i kalwinów ${ }^{65}$. W pierwszej książce autor przedstawił syntezę nauki Kościoła katolickiego i prawosławnego, opierając się na formule wyznania wiary, ogłoszonej w 1642 roku przez papieża Urbana VIII, w drugiej pisarz wyjaśnia różne kontrowersje występujące między wyznaniami, grupując je w hasła tematyczne, które zostały ułożone alfabetycznie (np. Anioł stróż, Anioł zły albo diabeł, Antychryst, Bierzmowanie, Bóg, Chrzest etc.). Na uwagę zasługuje również książka jezuity Tobiasza

${ }^{63}$ T. Krahel, Zarys dziejów (archi) diecezji wileńskiej, „Studia Teologiczne. Białystok, Drohiczyn, Łomża” 5-6 (1987-1988), s. 61-64; W. Jemielity, Sanktuaria maryjne w diecezji łomżyńskiej, Łomża 1991.

${ }^{64}$ Badacze niejednokrotnie podkreślali, że dominikanie szerzyli tradycyjną pobożność ludową, jak kult maryjny, eucharystyczny czy pasyjny. Zob. m.in.: M. Miławicki, Dominikanie na kresach wschodnich Rzeczypospolitej Obojga Narodów (teren dzisiejszej Białorusi), „, Folia Historica Cracoviensia”, 20 (2014) s. 95-153; M. Miławicki, Pobożność ludowa w pracy duszpasterskiej dominikanów na ziemiach polskich, „Teofil”, 13 (2005) nr 2, s. 55-110; tenże, Miejsce religijności ludowej w działalności duszpasterskiej dominikanów w Polsce pótnocno-wschodniej w okresie staropolskim, w: Parafia rzymskokatolicka w Choroszczy. 550 lat. Księga Jubileuszowa, red. T. Kasabuła, A. Szot, Białystok 2009, s. 101-221.

${ }^{65}$ P. Drogoszewski, Tarcza wiary Chrystusowej, która uzbrojony Polak latwo może przytępić oręż lutrów i kalwinów, Warszawa 1708; P. Drogoszewski, Tarcza wiary świętej rzymskiej kato-lickiej [...] Albo teologia polska, kontrowersje ikonkluzje katolickie alfabetycznym porzadkiem wsobie zamykająca, Przez księdza Wojciecha Ochabowicza zakonu dominikańskiego wydana, Lublin 1736; R. Świętochowski, Drogoszewski Piotr (1652-1729), w: Encyklopedia katolicka, t. 4, red. R. Łukaszyk, L. Bieńkowski, F. Gryglewicz, Lublin 1983, s. 223. 
Arenta, Studium polemicum pro Doctrina Catholica Susceptum ${ }^{66}$, w której autor omówił metody swojej pracy misjonarskiej, ponadto zawarł sposoby prowadzenia polemiki łącząc głęboką wiedzę ze szczerym uszanowaniem dla różnowierców. Arent przez 14 lat pracował jako misjonarz w Królewcu, starając się nawracać na katolicyzm protestantów i wykładowców Uniwersytetu Królewieckiego ${ }^{67}$. Nie jest jasne, które dzieło jezuity Franciszka Costera znajdowało się w omawianym księgozbiorze (zapis: „Libri Francisci Costero S Jesu”), ale można zwrócić uwagę, że jezuita ten znany był z pism, w których udzielał wyczerpujących odpowiedzi na sugestie protestanckich pisarzy. Natomiast o zainteresowaniu sprawami żydowskimi może świadczyć posiadanie Traktatu Samuela Rabina błąd żydowski pokazujacy ${ }^{68}$ czy też książka zapisana jako „Rozmowy z Żydami”.

W spisach książek dominikanów krasnoborskich znajdowały się dekrety i przywileje papieskie oraz listy papieskie. $Z$ zapisu „zebrania z listów papieskich" można wnioskować, że część dokumentów to manuskrypty. Przy innych pozycjach pisano wprost: „Rethorica manuscriptum”. Należy pamiętać, że rękopiśmienny obieg tekstów współistniał ze starymi drukami. Pisano i kopiowano teksty o różnej treści: naukowej, dotyczące legislacji, dotyczące spraw organizacji życia danej wspólnoty ${ }^{69}$.

Z zakresu nauk przyrodniczych, prawdopodobnie w celach szkolnych, mieli jedna z prac Johanna Sperlinga, siedemnastowiecznego niemieckiego lekarza, zoologa i fizyka - Exercitationes physicae. Dodatkowo w 1810 roku w spisach odnotowano również książkę księdza Krzysztofa Kluka, niestety lakoniczny zapis („Historyi X Kluka tomik”) nie pozwala na ustalenie tytułu, podobnie jak z leksykonem o tematyce filozoficznej („Dykcyonarz filozoficzny”). Inne, niezidentyfikowane materiały wskazują, że znajdowały się także książki o tematyce historycznej (np. "Liber historiarum bellicarum").

W księgozbiorze dominikanów krasnoborskich znalazły się książki wydawane zarówno w kraju, jak i za granicą. Ze względu na lakoniczne opisy książek nie można przeprowadzić gruntownej analizy miejsc wydania ${ }^{70}$. Niemniej jednak niektóre tytuły odnotowywano w bibliografiach jedynie pod jednym adresem wydawniczym, więc może to dać ogólną orientację na temat geografii wydawniczej omawianego księgozbioru. Wśród książek pochodzących z oficyn funkcjonujących na terenie Rzeczypospolitej, zdecydowanie przeważały druki wileńskie

${ }^{66}$ T. Arent, Studium polemicum pro Doctrina Catholica Susceptum in gratiam studiosae Juventutis Catholicae ex zelo apostolico ad parochias $v$ missiones acatholicis vicinas aspirantis, Wilno 1716.

${ }^{67}$ T. Oracki, Stownik biograficzny Warmii, Mazur i Powiśla, Warszawa 1963, s. 6.

${ }^{68}$ Samuel Rabi Marokański, Traktat Samuela Rabina Bład Zydowski Pokazuiacy, tłum. A. Bonihominis, Wilno [1705].

${ }^{69}$ J. Gwioździk, Biblioteka w kulturze zakonnej. Zarys problematyki, w: Biblioteki kościelne i klasztorne w Polsce. Historia i wspótczesność, red. H. Olszar, B. Warząchowska, Katowice 2009, s. 60; J. Maciejewski, Specyfikacja rękopiśmiennego obiegu literatury w XVI-XVIII wieku, „Napis” Seria VIII (2002) s. 3-14.

${ }^{70}$ Taką analizę udało się przeprowadzić dla kilku bibliotek dominikańskich prowincji litewskiej. Zob. Zimnoch, Historyczna biblioteka dominikańska w Różanymstoku, s. 127-147. 
(Drukarnia Akademicka), a następnie krakowskie i warszawskie. Dominikanie posiadali także druki wydane za granicą, przede wszystkim z oficyn niemieckich, zwłaszcza Kolonii i Augsburga. Były to najczęściej książki ze starszym rokiem wydania.

Po kasacie klasztorów, archiwa i biblioteki klasztorne uległy likwidacji, przemieszczaniu, znacznemu rozproszeniu lub zniszczeniu. Biblioteka krasnoborskiego konwentu dominikańskiego już po III rozbiorze zaczęła ulegać uszczupleniu - jak pisano wcześniej - liczba pozycji zmalała niemal o połowę. Niestety, nieznane są jej późniejsze szczegółowe losy. Źródła nie wskazują, gdzie trafiły książki z tego księgozbioru, a prowadzenie badań proweniencyjnych zawsze było dosyć trudne z powodu braku bezpośredniego dostępu do starych druków, braku katalogów i kartotek proweniencyjnych. Wiadomo, że kilka książek w proweniencją omawianego klasztoru znajduje się w Bibliotece Uniwersytetu Wileńskiego.

\section{Wnioski}

Książka zawsze odgrywała istotną rolę w społeczeństwie. W życiu zakonnym należy podkreślić zwłaszcza jej funkcję religijną, formacyjną oraz naukową i edukacyjną. Analizując zawartość dominikańskiego księgozbioru w Krasnymborze, można wyciągnąć kilka wniosków.

Mimo że klasztor dominikański w Krasnymborze był niewielką placówką zakonną to nie zabrakło tutaj podstawowej literatury, która służyła duchownym, zgodnie z charakterystycznym dla danego zakonu charyzmatem, $w$ ich formacji wewnętrznej, jak i w pełnieniu obowiązków duszpasterskich, oświatowych i kulturalnych.

W gromadzeniu księgozbioru widoczne są pewne zakresy tematyczne. Była to przede wszystkim literatura teologiczna i homiletyczna, maryjna oraz polemiczna. Wynikało to $\mathrm{z}$ form aktywności dominikanów, którzy słynęli z działalności kaznodziejskiej, misyjnej, edukacyjnej i sprawowania opieki nad kultem maryjnym. Należy pamiętać, że zakonnicy często wpływali na ludność parafialną, zwłaszcza w okresach specjalnego nasilenia akcji duszpasterskich, np. spowiedzi czy misji wielkopostnych. Przyczyniali się także do szerzenia tradycyjnej pobożności ludowej.

Dominikanie krasnoborscy posiadali kilka ciekawych i cennych zabytków piśmienniczych, m.in. Ewangelię w języku łotewskim.

Podsumowując, krasnoborski księgozbiór dominikański ukazuje dbałość o wiedzę i kulturę intelektualną, teologiczną, duszpasterską, nawet w niewielkim konwencie. Jego charakterystyka służy rozpoznaniu wkładu zakonu dominikańskiego w historię i kulturę tego regionu na przestrzeni wieków. 


\section{BIBLIOGRAFIA}

\section{Źródla}

Archiwum Diecezjalne w Łomży (AD Łomża)

dz. III, nr 12: Akta Konsystorza generalnego diecezji augustowskiej tyczące się funduszu dominikanów krasnoborskich, k. nlb.

\section{Opracowania}

Barącz Sadok, Cudowne Obrazy Matki Najświętszej w Polsce, [Lwów] 1891.

Barącz Sadok, Rys dziejów. Zakony Kaznodziejskie w Polsce, t. 2, Lwów 1861.

Brzozecki Sławomir, Litewska prowincja dominikanów, w: Dominikanie, Gdańsk, Polska, Europa. Materiały z konferencji międzynarodowej pt. Gdańskie i Europejskie Dziedzictwo zakonu dominikanów w dziejach Gdańska, red. A. Dekański, Gdańsk-Pelplin 2003, s. 139-165.

Čepienė Konstancija, Petrauskienė Irena, Vilniaus akademijos spaustuves leidiniai 15761805, Vilnius 1979.

Dobroński Adam, Krasnybór i dominikanie, Białystok 1993.

Evangelia toto anno 1753: pirmā latgaliešu grāmata, oprac. A. Stafecka, Ryga 2004.

Flaga Jerzy, Działalność duszpasterska zakonów w drugiej połowie XVIII wieku, Lublin 1986, s. 41-138.

Gach Piotr Paweł, Kasaty zakonów na ziemiach dawnej Rzeczypospolitej i Śląska 17731914, Lublin 1984.

Gałwiaczek Tomasz, Metafizyka w pejzażu. Obraz świata w kazaniach dominikańskich z I połowy XVIII wieku, w: Dominikanie na ziemiach polskich $w$ epoce nowożytnej, red. A. Markiewicz, M. Miławicki, Kraków 2009, s. 285-326.

Georgius Elger 1585-1672. Geistliche Catholische Gesänge... (Braunsberg 1621), oprac. M. Grudule, J. Prusinowska, M. Solarz, Warszawa 2018.

Grzebień Ludwik, Zaryczny Jacek, Języki narodowe w działalności jezuitów w Inflantach, „Analecta Cracoviensia”, (1995) nr 27, s. 404-405.

Grzebień Ludwik, Znaczenie jezuitów w Rzeczypospolitej na przełomie XVI i XVII w., „Studia Bobolanum”, 3 (2010) s. 49-50.

Guzewicz Wojciech, Skawiński Ryszard, Sanktuaria w diecezji ełckiej (1992-2012), „Civitas et lex", (2017) nr 3 (15), s. 67-76.

Gwiazda Halina, Fundacja i fundatorzy klasztorów dominikańskich w Wielkim Księstwie Litewskim w latach 1648-1696, w: Studia nad historia dominikanów w Polsce 12221972, t. 1, red. J. Kłoczowski, Warszawa 1975, s. 607-645.

Gwioździk Jolanta, Biblioteka w kulturze zakonnej. Zarys problematyki, w: Biblioteki kościelne i klasztorne w Polsce. Historia i współczesność, red. H. Olszar, B. Warząchowska, Katowice 2009, s. 54-64.

Jemielity Witold, Sanktuaria maryjne w diecezji łomżyńskiej, Łomża 1991.

Jemielity Witold, Zakonnicy $w$ duszpasterstwie, diecezja augustowska czyli sejneńska, „Prawo Kanoniczne: kwartalnik prawno-historyczny”, 41 (1998) nr 1-2, s. 149-171.

Keferstein Halina, Pisarze zwiazani z Braniewem na przełomie XVI-XVII wieku, „Komunikaty Mazursko-Warmińskie", (1980) nr 4, s. 507-530.

Kolbuszewski Stanisław Franciszek, Łukaszewicz Jan, w: Polski słownik biograficzny, t. 18 , Wrocław 1973 , s. 540-541.

Kościót katolicki na Podlasiu. Zbiór dokumentów erekcyjnych i funduszowych. Krasnybór, wstęp i oprac. G. Ryżewski, Białystok 2000. 
Krahel Tadeusz, Zarys dziejów (archi)diecezji wileńskiej, „Studia Teologiczne. Białystok, Drohiczyn, Łomża”, 5-6 (1987-1988) s. 7-72.

Kurczewski Jan, Biskupstwo wileńskie, Wilno 1910.

Łopaciński Hieronim, Najdawniejsze słowniki polskie drukowane, „Prace Filologiczne”, 5 (1899) s. 393-454, 586-605.

Maciejewski Janusz, Specyfikacja rękopiśmiennego obiegu literatury w XVI-XVIII wieku, „Napis”, Seria VIII (2002) s. 3-14.

Maroszek Józef, Klasztory Podlasia. Źródta kultury i świadomości narodowej, Białystok 1995.

Miławicki Marek, Dominikanie na kresach wschodnich Rzeczypospolitej Obojga Narodów (teren dzisiejszej Białorusi), ,, Folia Historica Cracoviensia”, 20 (2014) s. 95-153.

Miławicki Marek, Inwentarze i spisy bibliotek klasztorów dominikańskich skasowanych $w$ guberniach zachodnich Cesarstwa Rosyjskiego w XIX w. Stan źródet i miejsca ich przechowywania, „Hereditas Monasteriorum”, 1 (2012) s. 141-172.

Miławicki Marek, Miejsce religijności ludowej $w$ działalności duszpasterskiej dominikanów w Polsce pótnocno-wschodniej w okresie staropolskim, w: Parafia rzymskokatolicka w Choroszczy. 550 lat. Księga Jubileuszowa, red. T. Kasabuła, A. Szot. Białystok 2009, s. 101-221.

Moskal Tomasz, Dzieła homiletyczne kaznodziejów dominikańskich w XVIII-wiecznych bibliotekach archidiakonatu sandomierskiego, „Saeculum Christianum”, 16 (2009) nr 1, s. 129-136.

Pacevičius Arvydas, Vienuolunu bibliotekos Lietuvoje 1795-1864 metais, Vilnius 2005.

Pacevičius Arvydas, Žemaičiu Kalvarijos dominikonu bibliotekos autoriai ir knygos 1820 metais, „Knygotyra”, 36 (2000) s. 290-309.

Pelczar Józef Sebastian, Zarys dziejów kaznodziejstwa w kościele katolickim, cz. 2: Kaznodzieje Polsce, t. 2, Kraków 1896.

Petkus Viktoras, Dominikonai lietuvos kultūroje, Vilnius 2004.

Pidłypczak-Majerowicz Maria, Biblioteki i bibliotekarstwo zakonne na wschodnich ziemiach Rzeczypospolitej w XVII-XVIII wieku, Wrocław 1996.

Połujański Antoni, Kościót w Krasnymborze, w: Wieniec, Pismo zbiorowe ofiarowane Stanisławowi Jachowiczowi, t. 2, Warszawa 1858, s. 371-371.

Poplatek Jan, Świerkowski Ksawery, Elger Jerzy (1586-1672), w: Polski stownik biograficzny, t. 6, Kraków 1948, s. 227.

Potocki Andrzej, Biblioteka w dominikańskim studium, „Teofil”, 18 (2002) nr 2, s. 159-169.

Rok Bogdan, Człowiek wobec śmierci w kulturze staropolskiej, Wrocław 1995.

Ryżewski Grzegorz, Ród Chreptowiczów herbu Odrowąż. Dobra i kariera Chreptowiczów, Kraków 2006.

Ryżewski Grzegorz, Sztabin. Dzieje obszaru gminy Sztabin od czasów najdawniejszych do wspótczesności, Białystok-Sztabin 2002.

Szot Adam, Biblioteka dominikańska w Różanymstoku, „Bibliotekarz Podlaski” 2004, nr 8, s. 64-78.

Szpor Romuald, Biblioteka i archiwum świadkami życia wspólnoty dominikańskiej, „Życie i Myśl”, 27 (1977) nr 10, s. 45-56.

Ślusarska Magdalena, Kaznodziejstwo epoki stanisławowskiej - inspiratorzy, twórcy, odbiorcy, „Napis”, Seria II (1995) s. 106.

Świerkowski Ksawery, Wilno kolebka drukarstwa łotewskiego, Wilno 1932.

Tomalska Joanna, Stynace łaskami obrazy Matki Boskiej z Dzieciatkiem w kościołach dominikańskich zachodniej części dawnego województwa trockiego, w: Dominikanie na ziemiach polskich w epoce nowożytnej, red. A. Markiewicz, M. Miławicki, Kraków 2009, s. 369-392. 
Vilniaus universiteto bibliotekos paleotipai. Katalogas, oprac. N. Feigelmanas, I. Daugirdaite, P. Račius, Vilnius 2003.

Witkowska Aleksandra, The Cult of the Virgin Mary in Polish religiousness from the 15th to the 17-th Century, w: The common Christian roots of the European nations. An international colloqium in the Vatican, t. 2, Florence 1982, s. 467-478.

Wołyniak [Giżycki Jan Marek], Wiadomości o dominikanach prowincji litewskiej, cz. 1, Kraków 1917, s. 122.

Wróbel Wiesław, Biblioteka klasztoru dominikanów w Choroszczy w 1828 r. i starodruk St-47 ze zbiorów Biblioteki Uniwersyteckiej im. Jerzego Giedroycia w Biatymstoku, w: Małe miasta. Ślady przeszłości, red. M. Zemło, Lublin 2017, s. 257-274.

Zawadzka Krystyna, Ze źródet i stanu badań dotyczacych dawnych klasztornych bibliotek dominikanów w polskich prowincjach, „Nasza Przeszłość”, 39 (1973) s. 226.

Zimnoch Katarzyna, Biblioteka dominikańska w Choroszczy w XVII wieku, w: Parafia rzymskokatolicka $w$ Choroszczy - 550 lat: księga jubileuszowa, red. T. Kasabuła, A. Szot, Białystok 2009, s. 135-148.

Zimnoch Katarzyna, Historyczna biblioteka dominikańska $w$ Różanymstoku $w$ świetle dziewiętnastowiecznych źródet inwentarzowych - język i proweniencja wydawnicza księgozbioru, „Studia Podlaskie”, 21 (2013) s. 127-147.

Zimnoch Katarzyna, Historyczne księgozbiory dominikańskie w powiecie grodzieńskim województwa trockiego w XVII-XIX wieku, w: Arma nostrae militiae. Kultura książki i pisma Zakonu Kaznodziejskiego na ziemiach polskich, red. I. Pietrzkiewicz, M. Miławickiego, Poznań 2019, s. 69-85.

Żmuda Ryszard, Bibliografia publikacji o bibliotekach kościelnych za lata 1945-2015, Łódź 2016.

\section{Netografia}

Słowniki dawne $i$ wspótczesne. Internetowy przewodnik edukacyjny, red. M. Bańko, M. Majdak, M. Czeszewski, http://www.leksykografia.uw.edu.pl/ (dostęp: 20.06.2019). 


\title{
THE LIBRARY OF THE DOMINICAN MONASTERY IN KRASNYBÓR IN THE $18^{\text {TH }}$ CENTURY
}

\begin{abstract}
Summary
The Dominican monastery in Krasnybór in Trakai voivodeship was founded in 1684 by Konstancja Chreptowiczowa of Dolscy, Samuel Litawor Chreptowicz, the Ensign of Starodubow's widow and her son Andrzej. It was a small Dominican convent affiliated with the Lithuanian Guardian Angel province, which functioned on the border of the Polish Crown and Lithuania. Since its creation, the monks tried to gather an appropriate book collection. We can explore the 18th century's Dominican Library of Krasnybór thanks to the preserved Acts of the General Consistory of the Augustów Diocese, currently stored in the Diocesan Archive in Łomża. The contents of the book collection indicate that it was to serve the religious and spiritual advancement and the monks' pastoral work. A significant part of the monastery's library was theological and homiletic literature. It was supporting preaching and missionary activities. The Dominicans in Krasnybór also took care of the Marian painting (the painting of Our Lady of the Rosary), which also influenced the contents of the book collection. The convent also gathered literature that can be described as polemical. It is worth mentioning that the discussed Dominican library contains several very valuable writing monuments.
\end{abstract}

Keywords: historical book collections; monastery book collections; Krasnybór; Dominicans (Lithuanian province, Trakai voivodeship) 